\title{
“SE TIVER QUE FAZER VOU FAZER E QUERO VER A PREFEITURA DERRUBAR": ETNOGRAFIA NUM COLETIVO EM MEIO AO ORDENAMENTO TERRITORIAL DA CIDADE DE VITÓRIA - ES
}

\author{
"IF I HAVE TO DO I WILL DO AND I WANT TO SEE THE CITY TAKE DOWN": \\ ETHNOGRAPHY IN A COLLECTIVE IN THE MIDDLE OF THE TERRITORIAL PLANNING \\ OF THE CITY OF VITÓRIA - ES
}

\author{
Márcio Antônio Farias de Freitas ${ }^{2}$
}

RESUMO: O município de Vitória - ES tornou-se palco de discursos sobre "sustentabilidade" e “ecologização”, sobretudo a partir da década de 1990, com a criação do Projeto Vitória do Futuro, Programa Terra Mais Igual, Área de Proteção Ambiental do Maciço Central e seu Zoneamento Ecológico-Econômico, Plano Diretor Urbano, e também com a administração do Parque Estadual da Fonte Grande, transferida ao poder municipal pelo governo estadual. A partir de então, todo um aparato institucional é utilizado para fundamentar um conjunto de políticas desenvolvimentistas e discursos sobre "sustentabilidade" que desconsideram as matas dos morros e seus arredores como ambientes de socialização e pertencimento de diversos coletivos da cidade. Através de processos autoritários de ordenamento e remoção territorial - em busca da criação de uma "cidade verde" - é negada não só a existência de relações desses coletivos com o território, mas com os demais sujeitos que compõe a cosmografia do lugar, o que tem gerado diversos conflitos socioambientais. Nesse artigo busco demonstrar, através de uma etnografia, os efeitos dessa política ambiental municipal num desses coletivos, bem como a política do abandono e as restrições impostas pela Prefeitura Municipal de Vitória - PMV, além de como esse coletivo agencia suas formas de resistência às investidas dessa em tentar tirá-lo de lá.

Palavras- chave: Unidades de conservação. Ordenamento territorial. Ambientalismo. Conflito socioambiental Etnografia.

ABSCTRACT: The municipality of Vitoria - ES became the stage for discourses on "sustainability" and "greening", especially from the I990s onwards, with the creation of the Vitória do Futuro Project, Terra Mais Igual Program, Maciço Environmental Protection Area Central and its Ecological-Economic Zoning, Urban Master Plan, and also with the administration of Fonte Grande State Park, transfer to municipal power by the state government. From then onwards, an entire institutional apparatus is used to support a set of

\footnotetext{
I Uma versão preliminar deste artigo foi publicada nos ANAIS da VIII Semana de Ciências Sociais da Universidade Federal do Espírito Santo, realizada em 2014.

${ }^{2}$ Centro em Rede de Investigação em Antropologia (CRIA/Portugal) Doutor em Antropologia (Universidade Nova de Lisboa); mestre em Ciências Sociais; pós-graduado (Lato Sensu) em História Social e Gestão Ambiental; e graduado (bacharelado e licenciatura) em Ciências Sociais (Universidade Federal do Espírito Santo). Membro do Centro em Rede de Investigação em Antropologia (CRIA/Portugal).Email:m.ffreitas@hotmail.com.
} 
developmental policies and discourses on "sustainability" that do not consider the forests of the hills and their surroundings as environments for socialization and belonging to various groups in the city. Authoritarian processes of territorial ordering and removal - in search of the creation of a green city - not only the existence of collective relations with the territory, but with the other subjects that make up the cosmography of the place, is denied, which has generated several socioenvironmental conflicts. In this article, I seek to demonstrate, through an ethnography, the effects of this environmental policy in one of these groups, as well as the policy of abandonment and restrictions imposed by the Municipality of Vitória - PMV, in addition to how this collective acts as a means of resistance to the onslaught of this in trying to get him out of there.

Keywords: Conservation units. Territorial planning. Environmentalism. Socio-environmental conflict. Ethnography.

\section{A política do abandono}

Dentre os lugares de ocorrência desses conflitos envolvendo coletivos e o Estado, no alto do morro da Fonte Grande, num território conhecido como Campinho, imprensado, desde 1986, entre as duas secções do Parque Estadual da Fonte Grande, a PMV pretende unir e conectar às demais áreas "protegidas" incluídas na Área de Proteção Ambiental do Maciço Central, retirando as famílias que lá habitam há gerações. O "discurso verde” da PMV, visando a criação de uma "cidade paisagem" e "ecologicamente correta", ao ser mobilizado, desconsidera as formas de ocupação dos moradores presentes nas Áreas de Interesse Ambiental (AIA) e Zonas de Proteção Ambiental (ZPA), rotulando-as enquanto “insustentáveis” do ponto de vista ambiental.

O Campinho está localizado em Área de Interesse Ambiental e Zona de Proteção Ambiental, isso significa que o coletivo não pode melhorar suas casas, a PMV não investe em melhorias, próibe a ESCELSA de investir na iluminação e a CESAN em abastecimento de água e esgoto, criando, dessa forma, uma situação de precariedade para forçar a sair do lugar e, ao mesmo tempo, prevenir novas ocupações. Em minha trajetória etnográfica junto ao coletivo observei muito de perto essa situação, tanto nas narrativas dos moradores quanto na observação direta da falta de infraestrutura básica que o restante da cidade possui, em contraste com a situação do Campinho. Como numa conversa com dona Dilma 36 anos, antiga moradora do Campinho, que narra sua percepção sobre o sumiço dos agentes de combate à dengue da PMV, relacionando essa ausência ao fato do local em que mora ser hoje uma área de interesse ambiental:

\footnotetext{
${ }^{3}$ Foram criados nomes fictícios para preservar a identidade dos moradores.
} 
[...] o pessoal da dengue botou armadilha aqui, disseram que é pra pegar mosquito. Tem um tempão que aquele rapaz não vem aqui. Aquele outro, que cuida de botar remédio na água, tem mais de dois meses que não vem. Não sei o que está acontecendo. Eles não estão cuidando de nada aqui em cima. Eu acho que é por causa disso aí que você estava falando, área ambiental, área não sei o quê, que o pessoal que vinha cuidar não está vindo.

Pude observar diretamente o descaso do poder público com as condições das habitações existentes no território (PMV, 2009), confirmando o quadro geral de precariedade em que vive o coletivo, sem nenhuma previsão de melhorias habitacionais por parte da PMV, uma vez que o Campinho não constitui área de intervenção das obras do Programa de Aceleração do Crescimento - PAC2 previstas para a Poligonal 3 do Programa Terra Mais Igual - PTMI4.

O plano de manejo do Parque Estadual da Fonte Grade em 1996 já demonstrava uma realidade semelhante à observada recentemente no Campinho: "no entorno da UC observam-se as precárias condições das habitações existentes, (...) sem nenhuma condição de infraestrutura básica como água, luz, saneamento e transporte” (SEAG-IDAF et al., 1996, p. 26). Cabe acrescentar, nesse cenário, a dificuldade do coletivo quanto à inexistência de banheiro em suas residências, como no caso de dona Alice, mineira de São Lourenço, com 79 anos de idade, que mora há mais de cinquenta anos no Campinho nessa situação, ao lado de sua filha Marijane, que vive com esposo e cinco filhos.

Das 38 famílias do Campinho, 25 declararam que a energia de suas casas era de origem clandestina (PMV, 2009); no entanto, esse número é bem maior, já que todos os moradores afirmaram, em conversa informal, que a energia de suas casas é "gato", ainda que, na hora do cadastramento do PTMI, constrangidas ou preocupadas com possíveis punições pela PMV, declararam receber fornecimento de energia elétrica. Já em relação ao abastecimento de água, dezessete famílias informaram que era clandestino, dez que tinham água encanada, nove tinham poço artesiano e duas declararam que não possuíam água (Ibid.). Entretanto, as dez famílias que declararam possuir água encanada, recebem a mesma através de encanamentos que distribuem a água das bombas, ocorrendo de forma clandestina. O senhor Lenine, 6r anos, antigo morador da

\footnotetext{
${ }^{4}$ O Programa Terra Mais Igual, criado em 1998, e modificado em 2007, baseia-se no ordenamento do PDU da cidade para identificar suas I5 poligonais (PMV, 2007a) e em Zonas Especiais de Interesse Social (ZEIS). A Poligonal 3 é composta pelos morros da Santa Clara, Moscoso, Piedade, Fonte Grande e Capixaba, com um total de r.oo6 habitações e uma população de 3.397 pessoas (Id., 2012).
} 
Fonte Grande que possuía um bar no Campinho, explica que "não tem nada de CESAN, a água não chegou a subir lá não, vem só aqui embaixo, na jaqueira”. E seu Noé, 65 anos, narra sobre o motivo de não ter água da CESAN no Campinho:

não foi a CESAN que não quis colocar água aqui em cima, foi a prefeitura que embargou ela de botar água. Quanto mais ela colocar água mais o povo aglomera aqui e a prefeitura não tem interesse que ninguém venha aqui pra cima, ela quer tirar.

(...) quando eu vim pra cá já tinha esta água aí, só que no verão falta água direto, agora quando está chovendo não falta. Agora se fizer dois, três dias mesmo de sol, aí a água vai embora (dona Janete, 53 anos).

Conforme o Diagnóstico prévio das nascentes do Maciço Central, elaborado em 2007 pela SEMMAM, a água do Poço das Mangueirass "é inadequada ao consumo humano, (...) causando doenças de veiculação hídrica em seus usuários", por se constituir numa "bacia de contribuição com forte contaminação de origem animal e humana" (PMV, 2007c), situação esta conhecida pelo coletivo, como demonstra Marijane:

[...] crianças de fora que vem tomar banho naquela represa ali, vem aqui no poço (das Mangueiras) cospem, fazem xixi, fazem fezes, tudo aí dentro do poço. Por várias vezes eu já cheguei aqui cedo (...) encontrei fezes, encontrei tudo aí dentro, entendeu? Aí a gente vai limpar. (...). A prefeitura fez exames e mais exames e deu que a água está contaminada, entendeu? (...) E a prefeitura sequer fez um tratamento nessa água, ela não fez nada. Está contaminada? Está, mas não são eles que estão bebendo, é a gente, é a gente que está bebendo. A prefeitura não tomou iniciativa nenhuma, nenhuma mesmo, entendeu? É um absurdo isso! (ALMEIDA, 2012).

Além da falta e insalubridade da água e da precariedade da iluminação, as condições das habitações vêm corroborar a afirmação dos moradores de que o Campinho está abandonado, como registrado em mais um ator não-humano dessa rede (LATOUR, 2012), o Relatório das Famílias em Risco Habitacional - $2010^{6}$, que se constitui numa atualização da identificação,

\footnotetext{
${ }^{5}$ Uma das nascentes da Fonte Grande, localizada no Campinho.

${ }^{6}$ Todas as residências foram georreferenciadas, contando ainda com o grau de risco, material construtivo, número de cômodos e situação da unidade sanitária, bem como a caracterização da situação familiar. Das 274 edificações identificadas, I07 estão localizadas na Fonte Grande, sendo 39 no Campinho. Dessas edificações, cinco foram classificadas com risco geológico e estrutural muito alto; uma com risco geológico muito alto; oito com risco geológico e estrutural alto; e seis com risco estrutural alto; além de outras dezoito com risco geológico, estrutural, e geológico e estrutural médio ou baixo (PMV, 2010).
} 
mapeamento e caracterização das residências em risco geológico e estrutural da $\mathrm{P}_{3}$, identificadas no Plano Municipal de Redução de Risco - PMRR7 (PMV, 2010).

No trabalho de campo ficou evidente o processo de deterioração das habitações do Campinho, sendo essa situação inerente à lógica de expulsão das famílias em AIA do município, já que ao proibir intervenções em AIA, e ao não investir em melhorias habitacionais e/ou reconstruções, o poder público intervém oferecendo seu repertório de alternativas para garantir a remoção das famílias, como a indenização, o Bônus Moradia ou o Reassentamento, tendo ainda a possibilidade de antes serem atendidas pelo Aluguel Provisório ${ }^{8}$.

Uma dessas habitações é a de João, que representa muito bem a precariedade em que vive o coletivo. Localizada há aproximadamente 190 metros de altura, sem água ou banheiro, o piso é de terra batida, e segundo laudo da Defesa Civil de 23/04/2010, as paredes de seu lar de cerca de Iom $^{2}$ são de estuque:

\footnotetext{
7 O PMRR de Vitória foi realizado em 2006 pela Fundação Espírito Santense de Tecnologia - FEST, através de convênio entre a Prefeitura do Município de Vitória, Caixa Econômica Federal e Ministério das Cidades, por meio do Programa de Urbanização, Regularização e Integração de Assentamentos Precários. Foi elaborado um diagnóstico de risco geológico do município, com definição de setores de risco alto e muito alto e quantificação das moradias expostas a esses níveis; foram definidas as intervenções necessárias para erradicação de risco em cada setor mapeado, contemplando escopo de obras e indicação de remoções e serviços necessários, estimativa de custos para cada intervenção e hierarquização das intervenções. O estudo estabeleceu ainda "referenciais e diretrizes para o desenvolvimento e implantação de uma política pública municipal de gestão de riscos geológicos para as áreas de ocupação precária de todo o município de Vitória" (FEST, 2006). Foram mapeadas quatorze moradias na Fonte Grande, sendo cinco no Campinho, quatro numa área classificada como risco muito alto, localizada ao lado da Escadaria do Céu, atingindo as residências de dona Évora, dona Felipa, dona Samara, dona Rute e seu Fabrício. Não houve limpeza e remoção das bananeiras, desmonte e remoção dos blocos instáveis ao longo da Escadaria do Céu, muito menos a revegetação da encosta, conforme tinha sido indicado, mas foram providenciadas as remoções de cinco famílias, quatro contempladas com o Aluguel Provisório, ficando evidente a intenção da PMV: a retirada das famílias do Campinho. A outra área no Campinho classificada como risco alto teve como indicações a proibição da ocupação da área, a remoção da moradia e a revegetação de $400 \mathrm{~m}^{2}$ da encosta (Idem, 2007), sendo que as últimas duas ainda não ocorreram.

${ }^{8}$ Conforme Art. 13 da Lei no 6.967/o7, que institui o Programa Habitacional de Interesse Social no âmbito do Programa Terra Mais Igual, o Bônus Moradia é um projeto habitacional que, para viabilizar o acesso à moradia digna, autoriza o Município a adquirir os direitos sobre imóvel removido compulsoriamente em decorrência de projetos de intervenção urbana, preservação ambiental e remoção de áreas impróprias à habitação, do proprietário e/ou titular de direitos sobre o mesmo desde que resida no imóvel e não tenha optado pela permuta por unidade habitacional em Reassentamento ou pela indenização decorrente da desapropriação. E segundo o Art. 5, o Reassentamento é um projeto habitacional que objetiva viabilizar o acesso à moradia digna para todos os moradores removidos compulsoriamente em decorrência de projetos de intervenção urbana, preservação ambiental e remoção de áreas impróprias à habitação. Já conforme o Art. io, o Aluguel Provisório é um projeto que busca viabilizar a concessão temporária de subsídio, integral ou parcial, para locação de imóvel residencial por famílias inseridas nas áreas de intervenção do Projeto Terra, com renda familiar mensal de até três salários mínimos ou per capita de até meio salário mínimo, que, à conveniência do Poder Público, tenham optado pela inclusão no Projeto Reassentamento (PMV, 2007b).
} 
uma técnica construtiva antiga, que consiste no entrelaçamento de madeiras verticais fixadas no solo, com vigas horizontais de bambu amarradas entre si por cipós, dando origem a um painel perfurado que, após ter os vãos preenchidos com barro, transforma-se em parede. Tal edificação já é bastante antiga e encontra-se em precárias condições estruturais. Verificamos a existência de rachaduras nas paredes, telhas do tipo amianto furadas e trincadas, caibros que dão sustentação ao telhado apodrecidos, a instalação elétrica encontra-se irregular e sujeita a curto-circuito. Uma das paredes já apresenta adernamento acentuado, apresentando risco iminente de ruína. Devido ao precário estado estrutural da residência em questão, bem como ao fato de que a mesma localiza-se em AIA, a Defesa Civil orienta a remoção do munícipe do local (grifo nosso).

Esses laudos são emitidos pelos técnicos da Gerência de Defesa Civil da Secretaria de Assistência Social da PMV, após identificação pela equipe local do PTMI das edificações em risco que necessitam de visita técnica, visando à abertura de processo para encaminhamento para as diversas opções de remoção da PMV, bem como para o Aluguel Provisório. Como pode ser observado na tabela I, no período de 2007 a 2010, foram emitidos pela Defesa Civil doze laudos sobre treze residências do Campinho, sendo que num laudo foram contempladas duas casas. Dessas residências, oito foram identificadas com "risco estrutural alto", uma com "risco estrutural muito alto", duas com "risco estrutural e geológico alto” e apenas uma com risco geológico, classificado como "risco geológico alto".

Tabela I: Ocorrências dos riscos das edificações do Campinho

\begin{tabular}{|l|c|}
\hline Risco & Ocorrências \\
\hline Estrutural alto & o8 \\
\hline Estrutural muito alto & or \\
\hline Geomorfológico ou geológico alto & or \\
\hline $\begin{array}{l}\text { Estrutural e geomorfológico ou geológico } \\
\text { alto }\end{array}$ & 02 \\
\hline Não informado & or \\
\hline
\end{tabular}

Fica evidente que o risco das residências não está em sua localização em encostas, precipícios ou próximas às pedras com risco de rolar, mas devido à proibição de melhorias e conservação de sua estrutura, por estarem em área de interesse ambiental. Não é à toa que oito laudos propõem - conforme tabela 2 - "a demolição da residência devido à condição precária da mesma e por estar em área de interesse ambiental, e inclusão dos munícipes em um programa habitacional desta municipalidade", sendo que um laudo apenas informa, no espaço da proposta de ação necessária, que "a residência está localizada em área de interesse ambiental”, totalizando 
nove laudos que indicam esta mesma localização. Logo, se na AIA as famílias não podem realizar a manutenção de suas casas - o que a tornará com risco estrutural, sendo futuramente encaminhada aos programas habitacionais da PMV e sua casa demolida - o risco maior é o estrutural ou é a localização em AIA?

Tabela 2: Propostas dos laudos da Defesa Civil

\begin{tabular}{|l|c|}
\hline Proposta de ação necessária & Ocorrências \\
\hline $\begin{array}{l}\text { A demolição da residência devido à condição precária da mesma e por } \\
\text { estar em área de interesse ambiental, e inclusão dos munícipes em um } \\
\text { programa habitacional desta municipalidade }\end{array}$ & 08 \\
\hline $\begin{array}{l}\text { A Defesa Civil considera a área imprópria para habitação por ser uma área } \\
\text { de risco geológico }\end{array}$ & or \\
\hline $\begin{array}{l}\text { Risco de ruína e encaminhamento do relatório para a P3 pra conhecimento } \\
\text { e medidas cabíveis. }\end{array}$ & 03 \\
\hline A residência está localizada em área de interesse ambiental & or \\
\hline
\end{tabular}

Nota-se ainda que não ocorre o mesmo encaminhamento de retirada de famílias do bairro de Fradinhos por estarem também em área de encostas do PEFG, o que representaria, segundo a lógica da PMV aplicada ao Campinho, um "risco" para a preservação ambiental, o que nos faz entender que:

risco só é risco dentro de um contexto relacional. E a partir desta perspectiva, a hegemonia de certo entendimento a respeito da natureza do risco ambiental na cidade de Vitória penalizou práticas de agentes menos articulados politicamente na arena de disputa. O grupo que conseguiu definir o conceito do risco definiu as práticas não sustentáveis, além do projeto e controle sobre o espaço. Ações como estas por parte do poder público são capazes de consolidar a noção da "cidade sustentável" pautada na garantia da produtividade física do meio urbano em função da reprodução do capital (LOBINO et al., 2008, p. 5I).

As condições de risco geológico na localidade e estrutural das moradias no Campinho, identificadas através dos Relatórios de risco habitacional das famílias da Poligonal 3 (PMV, 2008; idem, 20I0) ficam subsumidas ao grande projeto ambientalista da "cidade verde", aplicando os recursos para as desapropriações e as transferências das famílias para outros locais garantidos pelo Programa Terra Mais Igual, financiado pelo Programa de Aceleração do Crescimento (PAC2).

Além da falta de saneamento, água, luz, pavimentação de vias, situação das habitações, etc., a ausência de segurança pública representa outro motivo de expulsão do coletivo do território, considerado por seu Ricardo, nascido e criado na Fonte Grande, como mais um exemplo do abandono do poder público no território: 
O policiamento é muito mal-feito, então o pessoal se sente inseguro e está abandonando o bairro (...). Uma história muito triste de abandono social. O processo de esvaziamento do bairro, o Estado está saindo de lá, agora a população tende a sair atrás, junto com a escola, as associações, os projetos sociais. O abandono completo do bairro pelo Estado, que deixa gurizinhos com armas na mão na disputa com a Piedade, o que não existia antes.

Conforme relatos de moradores, sempre muito reservados em abordar esse tema, o conflito entre os morros da Fonte Grande e da Piedade teve início numa partida de futebol no Campinho há cerca de quinze anos, quando, após uma entrada mais ríspida de um jogador, o agredido respondeu com tiros, sendo ambos integrantes do "movimento"9 dos respectivos morros. Desde então, se desencadearam e intensificaram ameaças, agressões, assassinatos, vingança e disputa por pontos de venda de drogas nos dois morros, que, conforme relato de moradores, "só acalma quando um grupo de um lado e um do outro são presos pela polícia”. Toda essa violência chegou ao ponto de impedir que moradores de um morro utilizem a unidade de saúde do outro, e que filhos de moradores de um morro frequentem a escola de ensino infantil do outro, configurando a imposição de mais uma proibição ao coletivo.

A situação de conflito fez surgir mais uma fronteira identitária (BARTH, 2003; idem, 2000) no morro da Fonte Grande, entre o Campinho e a parte baixa do morro, relacionada à manifestação da violência: "aqui é muito bom de morar, é tranquilo, não tem os tiros lá de baixo, lá tá tendo tiro direto. Pra baixo não tem lugar tranquilo, é só tiro, aqui em cima é tranquilo" (Beth, 25 anos). E mesmo que não tenham ocorrido no Campinho, nesse período de cinco anos de vivência no morro foram assassinados três moradores envolvidos no conflito - o filho de Dilma, o filho primogênito de Marijane, além de Lucas - e canceladas várias "subidas” à Fonte Grande pelos técnicos da $\mathrm{P}_{3}$, devido às notícias de tensão no morro, que também afetaram a minha pesquisa de campo, sendo inúmeras as vezes em que fui instruído pelos próprios moradores a não subir, principalmente nos períodos de guerra com a Piedade.

No início do ano de 2013, numa visita ao Campinho em companhia de uma assistente social da SEHAB, tive a oportunidade de conversar com a mãe de Marijane, dona Alice, 79 anos, que depois de ouvir um "bom dia, tudo bem com a senhora?" proferido por mim, disparou imediatamente a seguinte frase: “que nada, o Papai Noel subiu o morro vestido de preto”, já que

9 Como é chamado o tráfico de drogas nos morros. 
seu filho Erasmo, 49 anos, havia falecido em meados de setembro de 2012 com quadro de insuficiência vascular, e seu neto de 15 anos fora assassinado no último dia do ano.

Os bailes no alto do morro, as partidas de futebol, os carnavais de rua, os namoros à moda antiga e até as trocas de favores entre vizinhos (FREITAS et al., 20II) foram atingidas pelos tiros que passaram a estigmatizar a Fonte Grande como território da violência e do tráfico, frequentada cada vez mais por policiais, helicópteros e rabecões, na mesma proporção em que aparece nos noticiários policiais dos jornais e telejornais locais, além de expulsar muita gente do morro, inclusive do Campinho.

\section{A resistência do coletivo}

O coletivo encontra alternativas para várias situações adversas, como a falta d'água, luz elétrica, banheiro, segurança, etc., e, mesmo que a ausência do poder público, ausência de cidadania, já tenha feito saírem algumas famílias e descerem para a parte baixa do morro, muitos moradores resistem em continuar no território, ou melhor, desobedecem e sabotam às inúmeras investidas da PMV em domesticar e disciplinar o território. Se a antropologia é uma ciência de indisciplinados, sobre indisciplinados e para indisciplinados (VIVEIROS DE CASTRO, 2007) então, se eles não o fossem, o que estaria fazendo aqui?

Conforme James Scott $^{10}$ existem diversas formas cotidianas de resistência - armas de grupos com pouco poder - tais como a dissimulação, relutância, falsa submissão, fazer "corpo mole”, simulação de ignorância, boicote, fantasia, condescendência, teatralização, dentre outros (SCOTT, 20II; idem, 2002). Para permanecer no Campinho, o coletivo resiste de várias maneiras, com a instalação de gatos de energia, de bombas e caixas d'água; se recusando a assinar o Termo de Opção da $\mathrm{PMV}^{\mathrm{II}}$; construindo as casas, apesar das proibições; utilizando o valor do Aluguel

\footnotetext{
${ }^{10}$ Ao estudar os camponeses asiáticos, o autor leva em conta a ética de subsistência e um senso de justiça que permeia as relações recíprocas na comunidade que cria habilmente estratégias de resistência testadas no cotidiano das relações de poder em que está envolvida (SCOTT, 20II; idem, 2002). Com devidos cuidados para não confundir realidades distintas no tempo e no espaço, acredito que a resistência do coletivo pode ser compreendida à luz da perspectiva de Scott.

${ }^{11}$ O Termo de Opção, com timbres da PMV e do PTMI, identificação da edificação, número do setor e da casa, ao final deve ser datado e assinado pelo técnico e pelo morador, que recebe uma cópia do documento, identificado pelo nome, $\mathrm{CPF}$, estado civil e nome do companheiro, poligonal, seguido do seguinte texto:

(...) morador do bairro ___ da Poligonal 3 do Terra Mais Igual há anos, em virtude da necessidade de remoção do imóvel no qual resido e sou proprietário/detentor de
} 
Provisório para outros fins; buscando ainda denunciar sua situação nas mídias, dentre outras. Ações essas desprezadas pela PMV através de atribuições de má índole, falta de caráter, preguiça, falta de ética, fraude, enfim, diversos juízos de valor que desqualificam a resistência posta em prática pelo coletivo (SCOTT, 20II; idem, 2002).

\section{Gatos de água e luz}

Além da instalação de gatos de energia em todo o território, diante das dificuldades no abastecimento hídrico, alguns moradores construíram formas de captação e armazenamento da água da chuva, e outros investiram na compra de bombas para captar a água da CESAN que vai até a linha de AIA, como relataram duas irmãs da família Moura:

a CESAN nunca quis colocar água aqui, porque não queria que nós ficássemos aqui, aí demos um jeitinho e colocamos a bomba (Gisele, 47 anos).

Se nós temos esta água é porque tiramos do nosso bolso, a prefeitura não ajudou em nada, prefeitura, comunidade, nada (Marta, 43 anos).

Em final de 20ı2, Marijane colocou uma caixa de mil litros d'água ligada à da casa de dona Gisele (com cinco mil litros), localizada logo acima e que distribui água para várias residências de

seu núcleo familiar. A caixa de Gisele enche uma vez por semana, o que faz com que as outras casas racionem a água, levando a lavar peças pesadas no Poço das Mangueiras, e "mesmo com bomba a gente continua tomando banho de balde, já que o chuveiro gasta muita água". Não é todo dia que a água sobe e de vez em quando a bomba quebra, de modo que todo mundo fica sem água, fazendo com que seja preciso recorrer ao Poço das Mangueiras.

\section{A recusa da assinatura do Termo de Opção da PMV}

O processo de desapropriação de áreas no Campinho e seu entorno, para serem incorporadas ao parque, iniciou-se em finais da década de 90 , no entanto, o conflito socioambiental no Campinho passou a ganhar visibilidade a partir de 2009, quando a PMV, ao lado da política de não investimento em infraestrutura básica, através do Programa Terra Mais Igual - no intuito de remanejar a população do local sob a justificativa de ser AIA e ZPA ofereceu aos moradores do Campinho, através do documento “Termo de Opção", as "opções” de 
remoção, também conhecidas como "programas habitacionais" da PMV, sendo que alguns moradores não aceitaram assinar o documento, afirmando que não sairiam do Campinho.

Para a realização da 2- Etapa do Plano de Intervenção Urbanística da Poligonal 3, prevista para iniciar em 2010 - mas com início em 2013, mas já paralisada - e diante da necessidade de se definir o quantitativo de unidades habitacionais a serem implementadas no território, no período de 17 a 30 de setembro de 2009, ocorreu a "aplicação" do Termo de Opção junto aos moradores da Fonte Grande ${ }^{12}$, já realizada anteriormente nos outros bairros da $\mathrm{P}_{3}$ - Santa Clara, Moscoso, Piedade e Capixaba. Das 47 edificações mapeadas nesse território, foram assinados 32 Termos de Opção, já que seis moradores não assinaram por se tratarem de casos que necessitavam de uma resolução judicial; quatro não eram residências e cinco eram imóveis fechados. Como pode ser observado na tabela 3 abaixo, dos 32 moradores que assinaram o Termo, doze optaram pelo Reassentamento, ressalvando que não abririam mão de continuarem morando no bairro da Fonte Grande.

Tabela 3: Assinatura do Termo de Opção

\begin{tabular}{cc}
\hline Opção de remoção & Frequência \\
\hline Bônus Moradia & 07 \\
\hline Indenização & o1 \\
\hline Reassentamento & 12 \\
\hline Não aceita sair & 12 \\
\hline Total & 32 \\
\hline Não assinou & 15 \\
\hline Total geral & 47 \\
\hline
\end{tabular}

Outros doze moradores ${ }^{13}$ declararam que não queriam sair de suas residências e só aceitaram assinar o documento quando propus escrever à mão a opção "não aceita sair" ao lado das outras, sendo que o senhor Edson não concordou, declarando que nem isso aceitaria fazer.

\footnotetext{
12 No Campinho, o mapeamento das residências não seguiu a mesma metodologia adotada em 2008-2009 no diagnóstico socioeconômico (PMV, 2009), atendendo à lógica implantada em toda a área da Fonte Grande pela SEDEC, que dividiu o bairro em quatro setores, sendo que os setores or e 02 compreendem o Campinho.

${ }^{13}$ Além disso, o bar de seu Marcílio, o barraco de madeira de dona Felipa e outro de dona Rute, que afirmaram que recusariam a assinar, por se tratarem de estabelecimento comercial e edificações fechadas, não foram contemplados com o Termo de Opção.
} 


\section{Construções no Campinho}

Mesmo diante das proibições impostas pela PMV através de seus diversos instrumentos de "controle territorial”, as pessoas não deixaram de realizar melhorias em suas residências, como no caso de Marijane, que fez um "puxadinho" de madeirite como extensão da casa de sua mãe, pois a família crescia e não cabia mais nos dois cômodos da antiga residência. Na casa morava sua mãe, o irmão, ela com seu companheiro e os quatro filhos, sendo que Marijane estava de novo grávida.

Em 20I0, devido às chuvas do final de ano que causaram estragos às casas e encostas da Fonte Grande, Marijane trocou a madeirite por alvenaria e construiu uma cobertura para o carro da família que consegue descer pela estrada do PEFG, quando não chove. Assim comentou a abordagem da prefeitura:

O pessoal da prefeitura veio aqui e falou que não podia construir mas eu falei pra eles que se eu tiver que fazer eu faço mesmo e não tem conversa não (...). Eu falei pra eles que não adianta vir com um monte de "presepeira" não, que aqui não tem nenhum marginal não.

(...) Se tiver que fazer vou fazer e quero ver a prefeitura derrubar.

Devido às obras, essa moradora coleciona alguns relatórios de vistoria e autos de constatação da SEMMAM, além de um par desses documentos por supressão de vegetação. No início de 2012, finalmente Marijane construiu um banheiro no quintal de sua casa, onde ela, o esposo, seus filhos e a mãe - que até então morou sem banheiro em casa por mais de cinquenta anos - poderão enfim desfrutar desse "luxo" no morro.

Seu Juliano, em meados de 2013 finalmente construiu sua casa de alvenaria, do mesmo tamanho da anterior feita de madeira, que pretende demolir assim que concluir a casa nova, o que irá produzir novos efeitos para o relatório de vistoria e auto de constatação da SEMMAM.

\section{Sabotando o Aluguel Provisório}

Desde o cadastramento das famílias do Campinho realizado em 2009, onze já foram encaminhadas ao Aluguel Provisório devido aos riscos estruturais e geológicos indicados nos Relatórios de Risco (2008; 2010) e no Plano Municipal de Redução de Risco - PMRR. No entanto, apenas cinco famílias se mudaram e permanecem em outros bairros, já que as outras seis famílias ou não sacaram o dinheiro depositado pela PMV em contas abertas para tal fim; ou sacaram, se mudaram e voltaram para o Campinho; ou sacaram e nem saíram do lugar. Assim, mesmo diante 
da precariedade, falta de infraestrutura e insegurança no local, as pessoas retornam para suas casas, mostrando o forte vínculo afetivo, a identificação e pertencimento em relação ao Campinho.

C. recebeu o Aluguel Provisório em 2009, gastou o dinheiro dos três meses em que foi depositado em sua conta, mas não se mudou do Campinho, até que em 2010 assinou um documento da SEHAB intitulado Termo de Desistência do Aluguel Provisório. No período em que recebeu o Aluguel Provisório, teve dificuldade em conseguir uma casa para alugar:

Eu não saí porque quando eu procurei casa eu não consegui, não saí por causa disso. Todo mundo via que eu tinha quatro filhos pequenos e estava grávida de um, entendeu? As pessoas que alugavam casa não queriam, por causa de choro de criança, de recém-nascido, aí não consegui, entendeu? (...) Eu gastei o dinheiro do aluguel mesmo e ninguém tem que dar opinião não, aí a assistente social chegou aqui botando opinião que eu gastei o dinheiro do aluguel, um negócio que não é nem pra ela se intrometer, ela chegou aqui gritando que parecia que o dinheiro era dela. (...) Pra aluguel eu não saio não, só pra minha casa mesmo, entendeu?

Dona Alice também recebeu o Aluguel Provisório em 2009, gastou o dinheiro referente aos três meses mas não se mudou até início de 20II, quando registrou seu polegar no Termo de Desistência do Aluguel Provisório. Marijane disse que sua mãe pode até se mudar, mas sempre volta:

Ela já se mudou pra São Pedro, já mudou pra Serra, já mudou pra Cariacica, mas quando ela fala que vai voltar ninguém tira da cabeça dela. Quando ela fala de voltar, ela volta, bota uma roupa na sacolinha e se manda. Ninguém tira essa ideia da cabeça dela não. (...) ela já foi pra vários lugares mas não fica de jeito nenhum! Meu irmão fez um cômodo lá na Serra pra ela e ela não ficou. Meu outro irmão também fez e ela não ficou. Ela vai, fica animada, vai. Quando passa dois, três meses ela volta, ninguém segura ela pra voltar.

Em fevereiro de 2013, seguindo os atores e aproveitando a visita das assistentes sociais da SEHAB, lotadas na $\mathrm{P}_{3}$, à dona Samara, 79 anos, consegui conversar com ela com muito esforço, devido à sua dificuldade em ouvir e por fazer isso ao lado da equipe. Ela nasceu em Guaratinga (BA) e veio há cerca de doze anos de Rondônia, separada de seu esposo, seu Juliano, com o qual teve, entre outros filhos, duas moradoras do Campinho: Felipa e Rute. Dona Samara, mudou-se do Campinho em 2010, através do Aluguel Provisório, passando por várias casas em diversos bairros do município, como Vila Rubim, morro do Quadro e Santa Tereza, residindo hoje em Maria Ortiz, com seu companheiro Benjamim, de 67 anos.

Morando num apartamento de dois quartos, sala, cozinha e banheiro, água encanada e luz elétrica, o casal não precisa pegar água da fonte nem fazer as necessidades no mato, muito menos gato para ter energia. No entanto, além de pagar pela água e luz, a casa não tem quintal, como no 
Campinho, onde dona Samara, tinha bananeira, horta e galinhas, sobrando apenas um pequeno pé de boldo que trouxe do Campinho numa lata grande de manteiga, colocada ao lado da pia da cozinha. Dona Samara disse que tinha saudades de suas plantas, de suas galinhas e cachorros, e que não queria mais viver de aluguel: "quero logo minha casinha, com quintal, pra plantar meus remédios".

Outra situação comum na $\mathrm{P}_{3}$, não só com os moradores do Campinho, é o fato de alugarem casas num valor bem abaixo daquele pago pelo Aluguel Provisório para garantir recursos para outros gastos, além da despesa com as contas de água e luz.

\section{Dona Évora e suas casas}

Em 2009 dona Évora e seu Abel estavam morando numa casa ao lado da Escadaria do Céu, onde viveram por cerca de cinco anos, após terem saído da casa da família de dona Évora na Boca da Mata: "eu nasci, cresci, casei, tive filhos, lá em cima, era do meu pai. Lá em cima na Boca da Mata: (...) ali tudo era do meu pai, meu pai tinha uma roça de milho e de feijão, aí tinha tudo! Era uma chácara ali. (...) meu pai vendia manga, vendia milho, parece mentira (...)”. A casa original, com o terreno na Boca da Mata, heranças de seus pais, ruiu e seu Abel construiu outra no lugar.

Pouco antes de se mudar para a casa da Escadaria do Céu, dona Évora vendeu a casa para Dalva, mas argumenta que não vendeu o terreno, demonstrando sua resistência em se desfazer da terra de seus pais, como se tivesse seu umbigo nela enterradoi4 (OLIVEIRA, 1998), tentando, dessa forma, separá-la da casa:

Évora: ele pegou a casa, que é dele, ele dizia que a casa é dele, que foi ele que fez, e de fato foi mesmo, não tinha água, não tinha luz, ele que colocou, a casa foi ele que fez mesmo, lajota, tudo foi ele que comprou. Então ele pegou a casa que era dele e vendeu, mas o quintal eu não vendi, eu não vendi aquele quintal, aquele quintal a minha mãe lançou tudinho, foi medido, já foi passado para a prefeitura, chegou os carnezinhos (...) até a moça falou: 'a senhora fica com os carnezinhos guardados aí e não precisa pagar não, agora os carnezinhos ficam com a senhora, é como se fosse o documento dali' (...). Ele que vendeu, eu não vendi não. Mas o terreno continua sendo meu (...), agora lá mora outra

\footnotetext{
${ }^{14}$ João Pacheco de Oliveira, em seu texto Uma etnologia dos “índios misturados"?: situação colonial, territorialização $e$ fluxos culturais, esclarece que a expressão "enterrada no umbigo" traz para os nordestinos uma associação muito particular, já que nas áreas rurais há um costume das mães enterrarem o umbigo dos recém-nascidos para que eles se mantenham emocionalmente ligados a ela e à sua terra de origem, uma vez que esse ato mágico aumentaria as chances da criança retornar um dia à sua terra natal. O que a figura poética sugere é uma poderosa conexão entre o sentimento de pertencimento étnico e um lugar de origem específico, onde o indivíduo e seus componentes mágicos se unem e identificam com a própria terra, passando a integrar um destino comum. A relação entre a pessoa e o grupo étnico seria mediada pelo território e a sua representação poderia remeter não só a uma recuperação mais primária da memória, mas também às imagens mais expressivas da autoctonia. (OLIVEIRA, 1998, p. 64-65).
} 
pessoa, na casa que ele vendeu, o quintal não (...). Eu vou continuar com aquele quintal para mim, primeiro porque eu não vendi, porque eu sabia que aquilo era meu (...)

Abel: eu já expliquei para ela que eu tava vendendo o barraco, ela é que tem a terra.

Évora: Não, eu tenho é a herança.

Abel: Ela faz questão da terra.

Évora: Não, eu não faço questão da terra, eu faço questão da herança que meu pai deixou, eu já falei para você que eu não vou levar a terra (...) aquele terreno é herança do meu pai (...) é por isso que eu firmo o meu propósito com Deus.

Se dona Évora pretende ser indenizada pela prefeitura, por outro lado, Dalva argumenta que comprou a casa junto com o terreno e que desconhece outra situação onde se vende uma casa sem o terreno. Dona Évora mostrou-se muito apreensiva: não tem nenhum direito sobre a casa onde mora e reivindica a propriedade do terreno que diz não ter vendido, além de não possuir nenhum tipo de renda. A casa comprada na subida da Escadaria do Céu, localizada abaixo de um barranco com pedras e bananeiras, foi classificada pelo PMRR como em área de risco geológico muito alto, assim relatado por dona Évora:

[...] isto aí está tudo empilhado, e vai cair tudo. Isso aí é desde o tempo do meu pai, vai cair tudo. Eu passava aí para ir à escola, essa passagem é do tempo do meu pai, isso aí vai cair tudo. A gente pede socorro aqui, o povo não olha pra gente não, a gente mora em área de risco aqui, entendeu?

Em outubro de 2010 dona Évora e seu Abel mudaram-se para a parte baixa do morro da Fonte Grande, já que passaram a receber o Aluguel Provisório. A casa foi demolida pela PMV, mudando a paisagem do lugar, como pode ser observado nas fotografias i9 e 20 abaixo, permanecendo a lembrança de subir e descer a escadaria e sempre encontrar dona Évora, que perguntava curiosa aonde eu estava indo, contava alguma novidade do morro, e se despedia com seu típico "vai com Deus, que o Senhor o acompanhe".

Em 2013, quando conversei com dona Évora no escritório da $\mathrm{P}_{3}$, no mês de fevereiro, ela disse que continuava plantando jiló, abóbora, coentro, taioba, chuchu, boldo, manjericão, limão, batata doce, pimenta, dentre outros, no quintal atrás da casa onde mora de aluguel, na parte baixa do morro da Fonte Grande. Relatou ainda que havia pago a um vizinho para que trouxesse terra do quintal de sua casa demolida na Escadaria do Céu para poder plantar como lá em cima, com a mesma terra, como se o Campinho descesse junto. 


\section{Mostrando a cara do Campinho}

Encontrei Marijane na manhã do dia 26 de abril de 2012 na praça Mário de Oliveira Silva, na Fonte Grande. Eu estava subindo o morro - acompanhado de uma assistente social da SEHAB e de uma técnica em edificações da SEDEC - e ela estava descendo. Comprovando mais uma vez que também era um ator com agência seguido por outros atores (LATOUR, 200o), C. me chamou e disse que havia gravado um vídeo sobre o Campinho e que naquele momento estava indo para a casa de um primo para postar na internet. O vídeo intitulado Falta de qualidade de vida em pleno sec. 2 I - Prefeitura de Vitória, o mais recente ator não-humano presente na rede (Idem, 2012), está no YouTube $^{I 5}$ desde essa data e já teve mais de 500 visualizações. Foi uma forma que Marijane encontrou para expor e divulgar a situação do Campinho não só para a PMV, a UFES, mas para um público bem mais amplo que vai conhecer a situação de famílias que moram num lugar abandonado pelo poder público. No vídeo, gravado ao lado do Poço das Mangueiras, Marijane narra o cotidiano das famílias do Campinho em busca de água para beber, lavar roupa, vasilhas e tomar banho, sendo que sua mãe, dona Évora, que mora há mais de cinquenta anos no local, nunca teve água encanada em sua casa:

A maioria do nosso tempo é aqui no poço, toda a vida nós dedicamos ao poço, porque tudo que a gente vai fazer depende de água, como nós não temos água encanada, a gente tem que vir para o poço (...). A gente nunca teve um chuveiro, nem uma descarga, nem uma torneira em casa não. A gente conhece isso aí por duas coisas, trabalhar na casa dos outros ou visitar casa de alguém que tem, porque aqui nós não conhecemos isso não, entendeu? A nossa vida é assim há cinquenta anos, aqui é assim, entendeu? Quem viveu isso aqui há cinquenta anos, continua vivendo. (...) Eu acho que todo mundo deveria ter uma vida digna de ter uma torneira. Já pensou minha mãe tem setenta e oito anos e nunca teve acesso a uma torneira dentro de casa? Toma banho só de baldinho, ainda porque eu carrego, porque se eu não carregasse, ela que teria que vir neste pedregulho aqui tudo (...). Ele é o único poço, o único poço que existe aqui, não existe outro, tinha mais, mas secou. Se esse poço secar, é só Deus mesmo pra ter misericórdia de nós, porque nós não sabemos o que vamos fazer se esse poço secar. Graças a Deus que está aí cheinho, bonito, que Deus conserva assim, entendeu? Se esse poço secar, só Deus mesmo (...), porque não existe outro (ALMEIDA, 2012).

Além de destacar a problemática da falta de água encanada, Marijane denuncia o descaso da prefeitura em relação à qualidade de vida do coletivo, que vive no centro da capital do Espírito Santo, descaso esse entendido pelo fato do Campinho estar localizado em área de interesse ambiental e, através do "Projeto Terra", a PMV objetiva tirar as pessoas de lá:

Eu moro em Vitória e eu não tenho qualidade de vida nenhuma, nem eu nem as vinte e duas famílias que moram aqui, entendeu? Por que nós não temos isso? Porque a prefeitura

is http://www.youtube.com/watch?v=VHoGX7JRZTc. 
não faz nada aqui, a prefeitura nunca fez nada aqui, a prefeitura nunca fez nada (...). Aqui não tem uma estrada, não tem nada que a prefeitura tenha feito. Tá na hora da prefeitura descruzar os braços, olhar um pouco pela gente também, respeitar, porque a prefeitura não respeita não, isso aqui, isso aqui não é vida de cidadão de bem não (...). A prefeitura não faz nada porque quer isso aqui pra fazer área de preservação ambiental. (...) Mas que ela resolva o nosso problema também, porque a gente respeita as árvores, a gente respeita, falta só a prefeitura respeitar a gente que está aqui, porque desse jeito a prefeitura não está respeitando ninguém aqui, ninguém mesmo, entendeu? Ninguém mesmo! A gente bebendo água aí ó, de xixi, de cuspe, de fezes, de lama. Eu bebo água da chuva porque a água da chuva muitas das vezes está uma água mais limpa, no Centro de Vitória, no Centro de Vitória isso está acontecendo. Que aqui desceu aqui ó, está na Costa Pereira, no Centro de Vitória, isso é uma vergonha, vergonha pra nós não, vergonha pra prefeitura de Vitória, entendeu? (...) A prefeitura de Vitória devia tomar iniciativa logo, o que fazer da gente, porque não tem como a prefeitura querer um terreno da gente e tirar a gente das nossas casas, entendeu? Pra botar em aluguel sendo que é ela que quer o terreno aqui, não somos nós que queremos sair não, aqui quem quer sair mesmo, assim, daqui de cima, apesar de todo sofrimento, é só duas, três famílias, o resto ninguém quer sair não (...). Ela tem que tirar a pessoa daqui e botar dentro de uma casa, porque aqui nós estamos dentro de nossa casa, entendeu? Da nossa casa, não é em casa dos outro não, entendeu? (...) é ela que quer isso aqui, não é a gente, entendeu? É um absurdo isso, um absurdo mesmo, se a prefeitura não tem condições de comprar casa de todo mundo, ela faz o seguinte: a gente não está reclamando de viver aqui não, estamos reclamando só da água só (ALMEIDA, 2012).

Em junho de 2013, dona Évora compareceu ao escritório da $\mathrm{P}_{3}$ e informou que havia participado da Pré-Conferência da Assistência Social em Vitória ${ }^{16}$ e contou que no momento das intervenções, "no meio daquela gente da alta", se inscreveu, pediu a palavra e relatou a situação em que vivia:

Eu sou Évora, sou do Campinho da Fonte Grande, faço parte do CRAS, estou no Projeto Terra, e quero a minha casa que foi derrubada pela prefeitura e até agora não deram a minha casa. Há dois anos moro no aluguel com meu esposo e a gente não aguenta mais ficar mudando daqui pra lá, a gente quer a nossa casa, nem que seja um barraco de tábua, em nome de Jesus, se vocês não me derem eu volto pra lá. Aí todo mundo bateu palma e vieram falar comigo.

Disse que ficou animada em ir à imprensa e contar sua história, para ver se desta forma a prefeitura resolve seu problema. Esse tipo de atitude tem se repetido no escritório da $\mathrm{P}_{3}$, a "porta de entrada" (LATOUR, 200o) do coletivo na PMV, onde moradores do território - que recebem Aluguel Provisório ou não - comparecem prometendo denunciar, pressionando a PMV para a efetivação das ações da política pública municipal, tanto reivindicando respostas em relação aos encaminhamentos assinados desde 2009, quanto ao ingresso no Aluguel Provisório. Fabrício, 54 anos de idade, também "nativo" do Campinho, se mudou no final de 20Io, devido ao incêndio em sua casa, vivendo hoje de favor na casa de sua filha no morro da Capixaba. Comparece

${ }^{16} \mathrm{http}: / /$ www.vitoria.es.gov.br/secom.php?pagina $=$ noticias \&idNoticia $=11317$. 
constantemente no escritório solicitando Aluguel Provisório, que não é ofertado pelo município desde 20ı. Devido às inúmeras negativas recebidas, recentemente manifestou sua vontade em relatar seu caso à imprensa, além de estar conseguindo um advogado para "correr atrás" de seu Aluguel Provisório.

Dona Léia vem incessantemente solicitando o Aluguel Provisório no escritório da $\mathrm{P}_{3}$, já que desde outubro de 2012 vem pagando aluguel numa casa na Fonte Grande, com dinheiro do trabalho de seu filho Sandro, para cuidarem de seu João, ainda acamado. Dona Léia e seus filhos também afirmaram que irão à imprensa denunciar a situação em que se encontram, além de acionar a intervenção do Ministério Público. Em junho de 2013, dona Felipa, ao apresentar o recibo do aluguel para a assistente social da SEHAB no escritório da $\mathrm{P}_{3}$, perguntou se tinha novidade sobre o Reassentamento. Recebendo a negativa da técnica, disse estar cansada de viver de aluguel e que se demorasse muito, construiria um novo barraco no Campinho, onde vivera por cerca de 20 anos.

Mesmo à margem da infraestrutura existente na cidade, o coletivo está determinado em viver no Campinho, não abrindo mão de uma intensa relação com o território, laços de parentesco e de afinidade com os demais membros, resistindo e sabotando as imposições do poder público municipal, ao mesmo tempo em que vem tomando atitudes mais ostensivas, procurando dar visibilidade pública aos problemas do coletivo, reivindicando o reconhecimento de seus direitos, pressionando e exigindo do poder público municipal uma resposta à sua situação "provisória", já que seus integrantes ou vivem mudando de casa em casa - através do Aluguel Provisório - ou vivendo num território cada vez mais abandonado, sem qualquer investimento público, ainda não totalmente "verde", e muito menos, com cidadania.

\section{REFERÊNCIAS}

ALMEIDA, Clarice Ana Pereira de. Falta de qualidade de vida em pleno sec. 21. 2012. Vídeo disponível em: http://www.youtube.com/watch?v=VHoGX 7 JRZTc

BARTH, Fredrik. Temáticas permanentes e emergentes na análise da etnicidade. In: VERMEULEN, Hans \& GOVERS, Cora (Orgs). Antropologia da etnicidade: para além de ethnic groups and boundaries. Lisboa: Fim de Século, 2003.

O guru, o iniciador e outras variações antropológicas. Rio de Janeiro: Contra Capa, 2000. 
Fundação Espírito-Santense de Tecnologia - FEST. Plano Municipal de Redução de Risco de Vitória-ES - 2a Etapa: Elaboração do Plano Municipal de Redução de Risco - PMRR. Vitória, 2007.

FREITAS, Márcio Antonio Farias de; SOUZA, Edimilson Rodrigues de. Contos e encontros: ocupação de áreas de interesse ambiental e conflitos entre políticas públicas e comunidades locais em Vitória-ES. In: I Seminário Nacional da Pós-Graduação em Ciências Sociais. Vitória: UFES, 2011 .

LATOUR, Bruno. Reagregando o social: uma introdução à teoria do ator-rede. Salvador: EDUFBA, Bauru: EDUSC, 2012.

Ciência em ação: como seguir cientistas e engenheiros sociedade afora. São Paulo: Editora UNESP, 2000.

; WOOLGAR, Steve. A vida de laboratório: a produção dos fatos científicos. Rio de Janeiro: Relume Darumá, 1997.

LOBINO, Camilla; VITORINO, Igor; FILGUEIRAS, Márcio. O discurso da sustentabilidade e as práticas de re-ordenamento do espaço na Grande Vitória-ES. In: Revista Geografares. Vitória, no 6. 2008.

OLIVEIRA, João Pacheco de. Uma etnologia dos 'índios misturados'? situação colonial, territorialização e fluxos culturais. In: A viagem de volta: etnicidade, politica e reelaboração cultural no Nordeste indígena. Rio de Janeiro: Contra Capa, 1998.

Prefeitura Municipal de Vitória. Relatório de transição: Programa Terra Mais Igual. Vitória: Prefeitura Municipal de Vitória, 2012.

- Relatório das famílias em risco habitacional. Vitória: Prefeitura Municipal de Vitória, 2010.

Diagnóstico socioeconômico da comunidade do Campinho da Fonte Grande. Vitória: Prefeitura Municipal de Vitória, 2009.

- Relatório das famílias em risco habitacional. Vitória: Prefeitura Municipal de Vitória, 2008.

Decreto no 13.669: Altera o Decreto 10.131/98. Vitória, 2007a.

. Lei no 6.967/o7: Institui Programa Habitacional de interesse social no âmbito do Projeto Terra. Vitória, 2007b.

Diagnóstico prévio das nascentes do Maciço Central. Vitória, 2007c. 
SCOTT, James C. Exploração normal, resistência normal. In: Revista Brasileira de Ciência Política, no 5. Brasília, janeiro-julho de 2011, pp. 217-243.

Formas cotidianas da resistência camponesa. In: Raízes. Campina Grande, vol. 2I, no or, jan/jun. 2002 (pp. 10-3i).

SEAG-IDAF; SEMMAM; CEPEMAR. Plano de Manejo: Parque Estadual da Fonte Grande. Vitória-ES, 1996.

VIVEIROS DE CASTRO, Eduardo. A antropologia e a imaginação da interdisciplinariedade. In: Palestra concedida ao IEAD/UFMG, 2007. Disponível em 14 partes a partir de: http://www.youtube.com/watch?v=ryıkkrR VqYk 